\title{
Regular physical exercise, sedentarism and characteristics of dismenorrhea and premenstrual syndrome
}

\author{
Exercício físico regular, sedentarismo e características \\ da dismenorréia e síndrome pré-menstrual
}

Lívio Matheus Aragão dos Prazeres, Renan Guedes de Brito, Erika Silva Ramos*

Universidade Federal de Sergipe (UFS), Lagarto, SE, Brazil

\begin{abstract}
Introduction: Among the menstrual disorders of the female reproductive period, Premenstrual Syndrome (PMS) and Dysmenorrhea are the most prevalent. The intensity of the signs and symptoms in each of these conditions may compromise the physical, psychological and social well-being of the woman at the stage of the menstrual cycle. Objective: To compare the signs and symptoms of menstrual disorders in women who practice regular exercise or not. Methods: A cross-sectional study carried out on women who practice exercises regularly and sedentary women. The IPAQ questionnaires and the evaluation of signs and symptoms of dysmenorrhea and PMS were applied to non-sedentary and sedentary students from the Federal University of Sergipe, Campus Lagarto. Results: Both groups had similar data for mean age and the mean Body Mass Index (BMI), therefore, passive of comparison. The prevalence of dysmenorrhea was significantly higher among sedentary women, $82 \%$ in the sedentary group and $46 \%$ in the non-sedentary group ( $\mathrm{p}<0.001)$, as well as some negative impacts on the psychological, social and physical state of both PMS and dysmenorrhea. Conclusion: The prevalence of signs and symptoms of dysmenorrhea was significantly higher in the Sedentary Group. Analyzing the behavior of PMS in relation to the practice of physical exercises, it was observed that the signs and symptoms of depressed mood, fatigue, difficulty to concentrate, lack of interest in social and home activities were more significant in the Sedentary Group.
\end{abstract}

Keywords: Dysmenorrhea. Premenstrual Syndrome. Menstrual Disorders.

\footnotetext{
LMAP: BS, e-mail: liviiomatheus@hotmail.com RGB: PhD: e-mail: guedes_renan@hotmail.com ESR: MS, e-mail: erikase1@hotamail.com
} 


\section{Resumo}

Introdução: Entre os distúrbios menstruais do período reprodutivo feminino, a Síndrome Pré-Menstrual (SPM) e a Dismenorréia, são as mais prevalentes. A intensidade dos sinais e sintomas de cada uma destas afecções, podem comprometer o bem estar físico, psicológico e social da mulher na fase do ciclo menstrual. Objetivo: Comparar os sinais e sintomas de distúrbios menstruais em mulheres praticantes ou não de exercício físico regular. Métodos: Estudo transversal, realizado em mulheres praticantes de exercício físico regular e sedentárias. Os questionários IPAQ e de avaliação dos sinais e sintomas de Dismenorréia e SPM, foram aplicados em alunas de academia e da Universidade Federal de Sergipe, Campus Lagarto. Resultados: As integrantes dos grupos praticantes e sedentários foram semelhantes em relação à média de idade e a média de Índice de Massa Corpórea (IMC), sendo portanto, passivas de comparação. A prevalência de dismenorreia foi significativamente maior entre as sedentárias, sendo $82 \%$ no grupo sedentárias e $46 \%$ no grupo praticantes $(p<0,001)$ bem como alguns impactos negativos sobre o estado psicológico, social e físico, tanto das entrevistadas com SPM quanto com dismenorreia. Conclusão: A prevalência de sinais e sintomas de dismenorreia foi significativamente maior no Grupo de Sedentárias. Quando analisado o comportamento da SPM em relação à prática de exercícios físicos, foi constatado que os sinais e sintomas de: o humor depressivo, fadiga, dificuldade de concentração, falta de interesse em atividades sociais e de casa, foram significativamente mais expressivos no Grupo Sedentário.

Palavras-Chave: Dismenorreia. Síndrome Pré-Menstrual. Distúrbios Menstruais.

\section{Introduction}

The menstrual cycle is, in the concept of research and clinical practice, the period between the first day of a menstruation and the eve of the beginning of the next menstruation. It is estimated that $5-30 \%$ of reproductive age women have some type of menstrual disorder, and in the United States about 2.9 million annual examinations are carried out arising from menstrual disorders in women between 25 - 54 years $[1,2]$.

The symptoms may be related to one or more phases of the menstrual cycle, being: periodicity, intensity and length. The periodicity corresponds to the time interval between bleeds, usually described as around $24-35$ days. The intensity equivalent to the amount of blood removed during menstruation ( $30-80 \mathrm{ml}$ ) and length of blood loss varies from two to seven days ${ }^{1}$. Thus, the frequency of menstrual disorders are characterized by short or long menstrual cycle, or intermenstrual bleeding. The excessive menstrual bleeds, named intensity disorders, while prolonged period, the duration disorders.

Premenstrual Syndrome (PMS) and Dysmenorrhea can be the most prevalent menstrual disorders. When reported on the PMS, it is known that in cases where the symptoms occur in the premenstrual phase and have strong negative influence on psychological, social and physical functioning of women, with consequent reduction in their quality of life, is that characterize this syndrome. Its onset is around two weeks before menstruation and after the onset of menstrual flow there is rapid relief of signs and symptoms [3 - 5].

Congestive states that mainly affect the breast, abdomen and pelvis, water retention, headache, increased vaginal secretion, generalized vague pain, increased appetite, diarrhea, constipation, sweating, acne and back pain are characterized as somatic symptoms. The psychic symptoms include anger / irritability, anxiety, tension, emotional instability (depression, crying), insomnia / hypersomnia, changes in social and productive / labor relations $[6,7]$.

On the other hand dysmenorrhea is characterized by physical symptoms, where the pain is their main complaint. It can be described as inferior, cyclic, recurrent pelvic or abdominal pain associated with menstruation. The term is derived from Greek, meaning difficulty in menstrual flow [8], and can be classified as primary or secondary. The primary dysmenorrhea is the most common type diagnosed in adolescents; its signs and symptoms are not associated with visible structural abnormalities or any pelvic and gynecological disease. Secondary dysmenorrhea has an association with a clinically diagnosed condition such as polycystic ovary syndrome or endometriosis [9]. It affects $60 \%$ of women with systemic symptoms 
such as headache $(60 \%)$, back pain, nausea and vomiting (80\%), diarrhea (50\%), irritability (30\%), asthenia (45\%) [10].

Treatment options for these disorders include integrated and multiple actions among professionals of various academic backgrounds. Despite of drug treatments are safe and effective in some situations, changing lifestyle habits related to diet, regular physical exercise and body care, present more lasting effects in promoting the welfare and reduces signs and symptoms [11].

Physical activity has been characterized as any body movement produced by the skeletal muscles, which results in an energy expenditure above resting levels. In this way, it includes all activities performed daily, whether at work, leisure or other activities such as eating, clothing and walking [12].

Scientific data show that the level of physical activity of the individual to be assessed, it can be classified as very active, active, insufficiently active and inactive (sedentary) [13]. Some studies show that the level of physical activity in women interferes with the intensity of the signs and symptoms of menstrual disorders (dysmenorrhea and / or PMS), but they are few in number and inspire questions concerning scientific evidence of the benefits of regular physical activity.

This study aimed to compare the prevalence of signs and symptoms of dysmenorrhea and / or PMS in non-sedentary and sedentary women.

\section{Methods}

It is a field study, prospective and cross-sectional, conducted in women with reproductive age between 18-39 years, sedentaries or not. It was carried out in four gyms in the city of Lagarto, where the women who agreed to participate, were duly registered and assiduous trainers, and in the Federal University of Sergipe / Campus Lagarto, with the academics of the various courses in health sciences.

In addition to these initial selection criteria, all participants answered the International Physical Activity Questionnaire (IPAQ) that estimates the time spent during the week with physical activities of moderate and vigorous intensity under different everyday contexts, such as labor, daily transport, housekeeping, leisure and passive activities performed in the sitting position. The questionnaire was published on the short and long version [14], being here used the short version, which contains eight questions. In the end, the interpretation of the results of IPAQ, allows to classify the participants in: sedentary; irregularly active A; irregularly active $B$; active and very active. In Brazil this questionnaire was validated by MATSUDO in 2001 [13].

The application of this instrument started from the perception that both activities and physical exercises tend to present varying intensities and are sometimes difficult to specify. Thus, the classification of the IPAQ together with evidence of regular exercise in gyms, allowed composing the groups: Practitioners Regular Physical Exercise (Practitioner Group). The remaining classified as inactive or irregularly active $A$ and B comprised the Sedentary Group.

Later, instruments which investigated the occurrence and signs / symptoms of menstrual disorders, Premenstrual Syndrome and Dysmenorrhea, were applied.

To characterize the pre-menstrual symptoms, questionnaire was used for effective diagnosis of the syndrome (which has clinical validation) and easy to apply. The characteristics are described in 19 items, where 14 are related to the symptoms of PMS and 5 questions related to the consequences of these symptoms, which include work activities, at home and in the social sphere. For the diagnosis of PMS it is necessary that the patient had at least one moderate to severe symptom in items: 1 - 4 ; at least 4 symptoms in items 1-14; and at least $1 \mathrm{~A}-\mathrm{E}$ item. At the end, the disorder could be classified as: none / absent, mild, moderate and severe [15].

The dysmenorrhea questionnaire was made by Rodrigues et al, in 2011, and consists of 24 items that measure: socio demographic data (age and school situation / employment); weight and height for calculating body mass index (BMI); research of smoking (at least three cigarettes per day) and alcohol (at least one alcoholic drink per day); the practice of physical exercise (at least 30 minutes, three times a week); the characteristics of the menstrual cycle (menarche, regularity of the cycles, the amount of menstrual flow) and the presence, duration, severity, treatment and limitations of dysmenorrhea [16].

We excluded women who were submitted to clinical treatment to control menstrual disorders or who had a clinical diagnosis of polycystic ovarian syndrome, endometriosis or other gynecological and psychiatric conditions such as depression. After 
inclusion and exclusion criteria were considered, the final sample consisted of 100 women, 50 in the Practicing Group and 50 in the Sedentary Group.

The Shapiro - Wilk test was used to assess the normal distribution of data. For age and BMI mean and standard deviation were established, while for the other variables, and thus qualifying characteristics, was used non - parametric -Mann-Whitney Wilcoxon test for independent samples. As for the comparison of signals and symptoms of dysmenorrhea and PMS, among practitioners and Sedentary groups, we used the $G$ test to compare the data with more than two categories. The chi-squared test was used in the other comparisons. The level of statistical significance used for all tests was $\mathrm{p}<0.05$. The variables were calculated using the Software Bio Estat, version 5.3.

This research was approved by the Research Ethics Committee of the Federal University of Sergipe (CAAE 60884616.3.0000.5546). After explaining the objectives and method of the research, those who agreed to participate signed the Informed Consent (IC) that attends to the Resolution No. 466/12 of the National Health Council.

\section{Results}

After comparisons, it was found that both mean age $(24.1 \pm 5.3$ years practitioners in Group \pm 3.9 and 22.1 years in sedentary group), and mean Index Body weight $\left(21.9 \pm 4.0 \mathrm{~kg} / \mathrm{m}^{2}\right.$ practitioners group and $22.4 \pm 3.3 \mathrm{~kg} / \mathrm{m}^{2}$ sedentary group), the groups were similar and comparable, presenting $\mathrm{p}=0.1638$ and $\mathrm{p}=0.0932$, respectively.

All participants were classified according to IPAQ, and found that $9 \%(\mathrm{n}=9)$ were sedentary; $26 \%(n=26)$ irregularly active A; $15 \%(n=15)$ irregularly active $B ; 22 \%(n=22)$ active; and $28 \%$ $(n=28)$ very active, with the active or highly active in the practitioners group and the other in the sedentary group. That is, the classification of the IPAQ confirmed that the level of physical activity of the members of each group was divergent.

Predictably, when questioned about the evidence of menstrual cramps (dysmenorrhoea) in the last 6 months, $46 \%(n=23)$ of the Practitioners Group and 82\% $(n=41)$ of the Sedentary Group reported having suffered from this condition. When comparing these percentage values, there was a significant difference between the groups $(p=0.0004)$, as can be observed in Figure 1 .

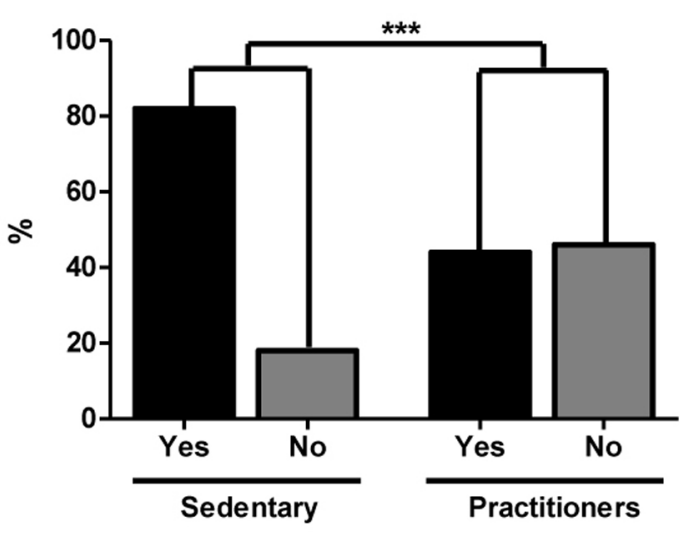

Figure 1 - Percentage distribution of dysmenorrhoea in women practicing regular or non-regular exercise (Practicing Group vs. Sedentary Group).

It was observed that when asked about the duration and intensity of dysmenorrhoea, the Practitioners Group presented slightly lower values compared to sedentary group, however, this difference was not significant with $\mathrm{p}=0.9892$ and $p=0.4221$, respectively (Table 1 ).

Table $\mathbf{1}$ - Distribution of the intensity and duration of menstrual pain among practitioners groups and sedentary numbers percentage, and the absolute value of $p$

\begin{tabular}{|c|c|c|c|}
\hline & 을 & 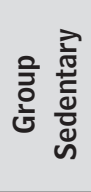 & P Value \\
\hline Intensity of menstrual pain & (\%) & (\%) & \\
\hline Light & 4.3 & 4.9 & \\
\hline Moderate & 65.2 & 63.4 & 0.9892 \\
\hline Severe & 30.4 & 31.7 & \\
\hline \multicolumn{4}{|l|}{ Duration of menstrual pain } \\
\hline$<24$ hours & 47.8 & 34.1 & \\
\hline 24 - 48 hours & 43.5 & 61 & 0.4221 \\
\hline$>48$ hours & 8.7 & 4.9 & \\
\hline
\end{tabular}

The volunteers who had dysmenorrhea in the last 6 months remained in the research on the symptoms associated to dysmenorrhea. In both groups, the most prevalent signs and symptoms were: irritability, fatigue, headache and breast pain. When the percentage values were compared, it was not possible to identify a significant difference between them (Table 2). 
Table 2 - Comparison of percentage values of symptoms associated with dysmenorrhea and $\mathrm{p}$ value, of both groups

\begin{tabular}{lccc}
\hline Symptomsassociatedwithdysmenorrhea & Practicing Group (\%) & Group Sedentary (\%) & P Value \\
\hline Diarrhea & 39 & 32 & 0.7447 \\
Headaches & 70 & 63 & 0.8237 \\
Fainting & 13 & 7 & 0,7587 \\
Irritability & 78 & 73 & 0.8804 \\
Vomiting & 17 & 15 & 0.9464 \\
Tiredness & 74 & 56 & 0.2528 \\
Breastpain & 70 & 59 & 0.5449 \\
\hline Difficulties caused by menstrual pain & $\mathbf{( \% )}$ & $\mathbf{( \% )}$ & \\
\hline Sleepdisorders & 39 & 32 & 0.7447 \\
Decreasedappetite & 26 & 29 & 0.9856 \\
Staying in bed for long periods & 52 & 46 & 0.8514 \\
Decreasedconcentration in class & 43 & 51 & 0.7384 \\
Interferencewithstudies & 52 & 54 & 0.6023 \\
Interferenceatwork & 22 & 17 & 0.9004 \\
Worsttestresults & 30 & 32 & 0.8606 \\
Interference with friends and colleagues & 43 & 51 & 0.7384 \\
Interference in sportspractice & 43 & 27 & 0.2785 \\
Interference in leisureactivities & 22 & 34 & 0.4489 \\
Depressed & 65 & 66 & 0.8237 \\
\hline
\end{tabular}

The participants who presented signs and symptoms characteristic of PMS, depressed $\operatorname{mood}(\mathrm{p}=0.001)$, fatigue $(\mathrm{p}=0.0118)$, difficulty in concentration ( $p=0.0204)$, lack of interest in social activities $(\mathrm{p}=0.0333)$ and the house ( $\mathrm{p}=0.0317$ ) had significant difference between the groups, being the Sedentary group more affected (Table 3 ).

Table 3 - Comparison of the percentage values of the signs and symptoms of PMS between groups

\begin{tabular}{|c|c|c|c|c|c|c|c|c|c|}
\hline \multirow[b]{2}{*}{ Signals and symptoms } & \multicolumn{4}{|c|}{ Sedentary $(100 \%, \mathrm{n}=50)$} & \multicolumn{4}{|c|}{ Practitioners $(100 \%, n=50)$} & \multirow[b]{2}{*}{ Value $p$} \\
\hline & 詈 & 泀 & $\begin{array}{l}\frac{0}{\pi} \\
\frac{\pi}{0} \\
\frac{0}{0} \\
\Sigma\end{array}$ & 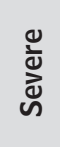 & 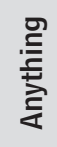 & 泀 & $\begin{array}{l}\frac{0}{\pi} \\
\frac{\pi}{0} \\
\frac{0}{0} \\
\Sigma\end{array}$ & 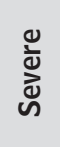 & \\
\hline Anger/Irritability & 12 & 24 & 46 & 18 & 6 & 18 & 42 & 34 & 0.2718 \\
\hline Anxiety / tension & 8 & 34 & 40 & 18 & 12 & 14 & 50 & 24 & 0.1386 \\
\hline Tearful & 26 & 18 & 24 & 32 & 18 & 8 & 32 & 42 & 0.2728 \\
\hline Depressive Humor & 38 & 38 & 14 & 10 & 24 & 14 & 46 & 14 & $0.001^{*}$ \\
\hline Lack of interest in work activity & 28 & 26 & 18 & 8 & 32 & 24 & 26 & 18 & 0.2376 \\
\hline Lack of interest in household activity & 42 & 28 & 14 & 16 & 16 & 30 & 24 & 28 & $0.0317^{*}$ \\
\hline Lack of interest in social activities & 48 & 22 & 24 & 6 & 26 & 30 & 20 & 22 & $0.0333^{*}$ \\
\hline Difficulty concentrating & 46 & 26 & 16 & 12 & 20 & 38 & 24 & 8 & $0.0204^{*}$ \\
\hline Fadigue & 26 & 34 & 28 & 12 & 18 & 12 & 40 & 30 & $0.0118^{*}$ \\
\hline Eating too much & 34 & 24 & 18 & 24 & 30 & 20 & 20 & 30 & 0.8788 \\
\hline Insomnia & 56 & 20 & 16 & 8 & 42 & 22 & 16 & 12 & 0.8347 \\
\hline Hypersonia & 58 & 14 & 10 & 18 & 32 & 24 & 22 & 22 & 0.0594 \\
\hline Feeling UnderPressure & 58 & 18 & 10 & 14 & 38 & 30 & 20 & 10 & 0.1564 \\
\hline PhysicalSymptoms & 58 & 18 & 10 & 14 & 4 & 12 & 38 & 46 & $0.0414^{*}$ \\
\hline
\end{tabular}

Note: ${ }^{*} p<0.05$. 
When asked about the interferences of these symptoms on daily life, work, functional and quality of life activities, it was notable that personal and social life activity $(\mathrm{p}=0.0028)$ and responsibilities at home $(p=0.0011)$ had significantly different values (Table 4).

Table 4 - Comparison of the interference caused by the signs and symptoms of PMS

\begin{tabular}{|c|c|c|c|c|c|c|c|c|c|}
\hline \multirow[b]{2}{*}{ SymptomInterference } & \multicolumn{4}{|c|}{ Sedentary $(\%, n=50)$} & \multicolumn{4}{|c|}{ Practitioners $(\%, \mathrm{n}=50)$} & \multirow[b]{2}{*}{ Value $p$} \\
\hline & 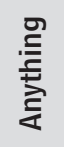 & 泀 & $\begin{array}{l}\text { गँ } \\
\text { एँ } \\
\frac{0}{0} \\
\Sigma\end{array}$ & 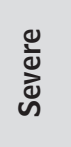 & 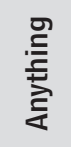 & 苛 & $\begin{array}{l}\frac{0}{\pi} \\
\frac{\pi}{ \pm} \\
\frac{0}{\Sigma} \\
\Sigma\end{array}$ & 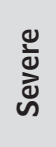 & \\
\hline Efficiency and productivity at work & 30 & 24 & 38 & 8 & 40 & 34 & 24 & 2 & 0.1813 \\
\hline Relationships with colleagues at work & 26 & 26 & 34 & 10 & 36 & 28 & 30 & 4 & 0.478 \\
\hline Relationship with Relatives & 16 & 38 & 28 & 16 & 30 & 28 & 34 & 8 & 0.2184 \\
\hline Personal activities and social life & 12 & 38 & 38 & 12 & 42 & 32 & 24 & 2 & $0.0028 *$ \\
\hline Responsibilitiesat home & 22 & 36 & 18 & 24 & 48 & 28 & 22 & 2 & $0.0011^{*}$ \\
\hline
\end{tabular}

Note: ${ }^{*} p<0.05$.

\section{Discussion}

The dysmenorrhea and PMS are topics discussed by many authors, in view of the negative impact that these conditions can generate on the physical and psychological condition of women at reproductive age. The participants relate the pain like menstrual cramping, with acute attacks manifested hours before or during menstruation [17 - 21].

The awareness that both diseases can compromise the social, laboral and functional relationships, encourage the search for effective therapies with minimal side effects. It is estimated that the practice of regular physical exercise reduces signs and symptoms related to dysmenorrhea and PMS [20, 22].

It is known that dysmenorrhea can be present in $90 \%$ of the female population in its reproductive period, beginning between 6 and 18 months after menarche and reaching its peak between 18 and 24 years old, and may show improvement after some time or after pregnancy and birth [11].

Regarding to primary dysmenorrhoea, it can be observed in a study conducted by Araujo [10] the effective reduction of pain signals in women who have adopted Pilates as treatment. This study included only women with a mean age of $20.3 \pm 2.06$ years and BMI $20.84 \pm 45 \mathrm{~kg} / \mathrm{m}$, classified as sedentary by IPAQ and insufficiently active A. After regular training with Pilates, these women showed a significant variation on the intensity of menstrual pain, where the average
Visual Analog Scale (VAS) decreased from $7.89 \pm 1.96$ to $2.56 \pm 0.56(\mathrm{p}<0.001)$. The Pilates Method is a dynamic technique, whose objectives are to promote stretching, flexibility and muscle strength, and the abdomen as the center of force, working continuously in all the exercises and techniques. It also proposes stimulation of body circulation and improvement in physical fitness [23].

When the University Adventist Center of São Paulo (UNASP) evaluated the levels of physical activity and dysmenorrhea of 100 university students, aged 18 to 26 years, those who were characterized as sedentary by the IPAQ obtained a level of pain in the EVA, significantly higher [24].

This study evaluated patients with similar characteristics to the work of Araújo [10] and despite of not having evaluated the effects of a specific type of exercise nor having measured the intensity of pain of the participants by EVA, it was found that the Practitioner Group had fewer women with dysmenorrhea complaints $(p<0,05)$. However, when those who had dysmenorrhoea (both groups) were asked about the intensity of menstrual pain, the percentages were similar. This result in particular, requires more studies.

We emphasize that in our study, the finding of dysmenorrhea occurred from the report of those evaluated, and a precise clinical diagnosis was not made to rule out secondary dysmenorrhea or to classify the severity of the condition. Moreover, among the components of the Practitioners Group, 
there was a difference between the types of realized exercise, aerobic, resistance and aerobic + resistance (combined). Perhaps, this information would help to better interpret this result.

In a study by Nunes [11], academics with dysmenorrhea in the course of Phisiotherapy from the Federal University of Piauí, the following variables were evaluated: pain intensity, signs and symptoms, school absenteeism and the level of physical activity practiced by them. When assessing the most prevalent symptoms this author found that headaches, mastalgia and irritability were evidents. These results corroborate the results obtained in this study in both groups.

Here, it was observed that, in both groups, more than $50 \%$ of the evaluated ones reported interference in the studies. This fact can be corroborated by Nunes [11], to establish a correlation between the intensity of menstrual pain and school absenteeism. Those who reported school absenteeism, 39.1\% reported moderate pain and $77.8 \%$ had severe levels of pain.

SPM is characterized by a set of behavioral changes, physical, cognitive and mood, which directly interfere in daily activities 2 . Where as in Brazil the prevalence can reach $43.3 \%$, it is estimated that $96.6 \%$ of women have at least one of several symptoms [25 - 27].

The practice of physical activities can also reduce premenstrual symptoms. The AmericanCollegeofObstetricianandGynecologists recommends regular exercise as non - drug treatment option for PMS 2, even though evidences to the type (aerobic or resistance) duration or intensity (mild, moderate or severe), for more effective control of this disease are incipients.

In a survey of 71 universities in the city of Juiz de Fora, Teixeira \& Oliveira [3] tested the hypothesis of a correlation between the physical activity level (PAL) and the symptoms of PMS. They found that the more prevalent premenstrual symptoms were: nervous tension, irritability, crying, insomnia, anxiety, change in mood, headache and fatigue. Besides that, it was observed that those who were diagnosed with PMS had significantly lower levels of physical activity than healthy women. This finding confirms the hypothesis that the level of physical activity and consequently regular physical exercise, decrease the prevalence and intensity of signs and symptoms of PMS.
Irritability complaints, anxiety, depression, isolation, headache and breast tenderness were the most prevalent signs and symptoms in this research as those developed by Gaion in the Northwestearn region of Paraná and David et al. [25, 26].

Similar complaints were also present in the studies of Câmara [28] and Nogueira [29]. In the first, in addition to considering the severity of menstrual disorders discussed here, also found complaints of abdominal swelling. In the study by Nogueira [29], in addition to breast pain symptoms, irritability, depression and headache, there were complaints associated with fatigue or pain in the legs, abdomen and spine. On the other hand, the insomnia and decreased interest in activities at home, were the least reported.

According to David [26], women who suffer with severe SPM may continue suffering from these signs and symptoms even after the pre - menstrual period. When this happens, the symptoms are regular and less intense. It was not the subject of this research to investigate the permanence of these signs and symptoms after the premenstrual period.

Among the repercussions of the sintom the PMS, Ferreira and Barroso $[30,31]$ claimed that there may be a direct impact on women's work and intimate life, generating guilt, anguish and emotional changes that compromise the housework, generating even more feelings of dissatisfaction. It is worth to point out that in our study there was significant interference in home activities and social life of those who reported signs and symptoms of PMS [30, 31].

\section{Conclusion}

Considering the sample in our study, the prevalence of signs and symptoms of dysmenorrhea was significantly higher in the Sedentary Group. Those women who had dysmenorrhea, had similar intensity and duration of symptoms between groups, and were also similar the symptoms of irritability, fatigue, headache, breast pain and interference on studies, the most prevalent. When analyzed the behavior of PMS in relation to the practice of physical exercises, it was observed that the signs and symptoms of: depressed mood, fatigue, difficulty concentrating, lack of interest in social and home activities were more significant in the Sedentary Group. 


\section{References}

1. Barcelos RS, Zanini RV, Santos IS. Distúrbios menstruais entre mulheres de 15-54 anos de idade em Pelotas, Rio Grande do Sul, Brasil: estudo de base populacional. Cad Saude Publica. 2013;29(11):2333-46.

2. Melo NR, Machado RB, Fernandes CE. Irregularidades menstruais -inter-relações com o psiquismo. Rev Psiquiatr Clin. 2006;33(2):55-9.

3. Teixeira ALS, Marques e Oliveira EC, Dias MRC. Relação entre o nível de atividade física e a incidência da síndrome pré-menstrual. Rev Bras Ginecol Obstet. 2013;35(5):210-4.

4. Proctor M, Farqhuhar C. Diagnosis and management of dysmenorrhoea. BMJ. 2006;332(7550):1134-8.

5. Beznos GW. Distúrbios menstruais. Pediatria Moderna. 2014;38(8):372-5.

6. Approbato MS, Araújo e Silva CD, Perini GF, Miranda TG, Fonseca TD , Freitas VC. Síndrome Pré-Menstrual e Desempenho Escolar. Rev Bras Ginecol Obstet. 2001; 23(7):459-62.

7. Silva CML, Gigante DP, Carret MLV, Fassa AG. Estudo populacional de síndrome pré-menstrual. Rev Saude Publica. 2006;40(1):47-56.

8. Motta EV, Salomão AJ, Ramos, LO. Dismenorreia. Rev Bras Med. 2000;57(5):369-86.

9. Reis CAAS, Hardy E, Sousa MH. The effectiveness of connective tissue massage in the treatment of priary dysmenorrhea among young women. Rev Bras Saude Matern Infant. 2010;10(2):247-56.

10. Araújo LM, Silva JMN, Bastos WT, Ventura PL. Diminuição da dor em mulheres com dismenorreia primária, tratadas pelo método Pilates. Ver Dor. 2012;13(2):119-23.

11. Nunes JMO, Rodrigues JA, Moura MSF, Batista SRC, Coutinho SKSF, Hazime FA, et al. Prevalência de dismenorreia em universitárias e sua relação com absenteísmo escolar, exercício físico e uso de medicamentos. Rev Bras Promoc Saude. 2013;26(3):381-6.

12. Glaner MF. Concordância de questionários de atividade física com a aptidão cardiorrespiratória. Rev Bras Cineantropom Desempenho Hum. 2007;9(1):61-6.
13. Matsudo S, Araujo T, Matsudo V, Andrade D, Andrade E, Oliveira LC, et al. Questionário internacional de atividade física (IPAQ): estudo de validade e reprodutibilidade no Brasil. Rev Bras Ativ Fis Saude. 2001;6(2):5-18.

14. Benedetti TRB, Antunes PC, Rodriguez-Añez CR, Mazo GZ, Petroski EL. Reprodutibilidade e validade do Questionário Internacional de Atividade Física (IPAQ) em homens idosos. Rev Bras Med Esporte. 2007;13(1):11-6.

15. Henz A. Diagnóstico da síndrome pré-menstrual: comparação de dois instrumentos - registro diário de intensidade dos problemas (DRSP) e instrumento de rastreamento de sintomas pré-menstruais (PSST) [master's thesis]. Porto Alegre: Universidade Federal do Rio Grande do Sul; 2016.

16. Rodrigues AC, Gala S, Neves ÃPC, Meirelles C, Frutuoso C, Vitor ME. Dismenorreia em adolescentes e jovens adultas prevalência, factores associados e limitações na vida diária. Acta Med Port.2011;24(S2):383-92.

17. Diegoli MSC, Diegoli CA. Dismenorreia. Rev Bras Med. 2007;64(3):81-7.

18. Acqua RB, Bendlin T. Dismenorreia. Femina. 2015;43(6):273-6.

19. Araujo IM, Leitão TC, Ventura PL. Estudo comparativo da eficiência do calor e frio no tratamento da dismenorreia primária. Rev Dor. 2010;11(3):218-21

20. Cardoso TSM, Leme APCBP. A equivalência da dança do ventre à cinesioterapia na terapêutica da dismenorréia primária. Fisioter Bras. 2003;4(2):96-102.

21. Halbe HW. Tratado de ginecologia. 3th ed. São Paulo: Roca; 2000.

22. Gerzon LR, Padilha JF, Braz MM, Gasparetto A. Fisioterapia na dismenorreia primária: revisão de literatura. Rev Dor. 2014;15(4):290-5.

23. Sekendiz B, Altuna O, Korkusuz F, Akin S. Effects of Pilates exercise on trunk strength, endurance and flexibility in sedentary adult females. J Bodyw Mov Ther. 2007;11(4)318-26.

24. Quintana LM, Heinz LN, Portes LA, Alfieri FM. Influência do nível de atividade física na dismenorreia. Rev Bras Ativ Fis Saude. 2010;15(2):101-4. 
25. Gaion PA, Vieira LF. Prevalência de síndrome prémenstrual em atletas. Rev Bras Med Esporte. 2010;16(1):24-8.

26. David AM., Bella ZJ, Berenstein E, Lopes AC, Vaisberg M. Incidência da síndrome pré-menstrual na prática de esportes. Rev Bras Med Esporte. 2009;15(5):330-3.

27. Rasheed P, Al-Sowielem LS. Prevalence and predictors of pré-menstrual syndrome among college-aged women in Saudi Arabia. Ann Saudi Med. 2003;23(6):381-7

28. Câmara DLA. Síndrome Pré-Menstrual Estudo de prevalência em alunas da Universidade da Beira Interior [master's thesis]. Covilhã, Portugal: Universidade da Beira Interior; 2011.
29. Nogueira CWM, Pinto e Silva JL. Prevalência dos Sintomas da Síndrome Pré-Menstrual. Rev Bras Ginecol Obstet. 2000;22(6):347-51.

30. Ferreira TF. Síndrome pré-menstrual: percepções de mulheres. Rev Bras Enferm. 1998;51(2):341-2.

31. Barroso C. Trabalho e saúde da mulher. Rev Bras Saude Ocup. 1982;38(10):7-11.

Received in 08/07/2017

Recebido em 07/08/2017

Approved in 10/16/2017

Aprovado em 16/10/2017 